\title{
COVID-19 - Toward a comprehensive understanding of the disease
}

\author{
Maciej M. Kowalik ${ }^{1}$, Piotr Trzonkowski ${ }^{2}$, Magdalena Łasińska-Kowara ${ }^{1}$, \\ Andrzej Mital ${ }^{3}$, Tomasz Smiatacz ${ }^{4}$, Miłosz Jaguszewski ${ }^{5}$ \\ ${ }^{1}$ Department of Cardiac Anesthesiology, Medical University of Gdansk, Poland \\ ${ }^{2}$ Department of Medical Immunology, Medical University of Gdansk, Poland \\ ${ }^{3}$ Department of Hematology and Transplantology, Medical University of Gdansk, Poland \\ ${ }^{4}$ Medical University of Gdansk, Poland \\ ${ }^{5} 1^{\text {st }}$ Department of Cardiology, University Catheterization Laboratories, \\ Medical University of Gdansk, Poland
}

\begin{abstract}
The evidence on the pathophysiology of the novel coronavirus SARS-CoV-2 infection is rapidly growing. Elucidating why some patients suffering from COVID-19 are getting so sick, while others are not, has become an informal imperative for researchers and clinicians around the globe. The answer to this question would allow rationalizing the fear surrounding this pandemic. Understanding of the pathophysiology of COVID-19 relies on unraveling of interplaying mechanisms, including SARS-CoV-2 virulence, human immune response, and complex inflammatory reactions with coagulation playing a major role. An interplay with bacterial co-infections, as well as the vascular system and microcirculation affected throughout the body should also be examined. More importantly, a comprehensive understanding of pathological mechanisms of COVID-19 will increase the efficacy of therapy and decrease mortality. Herewith, the authors present a combined viewpoint based on the current state of knowledge on COVID-19: beginning from the virus, its transmission, and mechanisms of entry into the human body, through the pathological effects on the cellular level, up to immunological reaction, systemic and organ presentation. Last but not least, currently available and possible future therapeutic and diagnostic options are briefly commented on. (Cardiol J 2020; 27, 2: 99-114)
\end{abstract}

Key words: COVID-19, SARS-CoV-2, epidemiology, immunology, acute respiratory distress syndrome, coagulation, therapy

\section{Introduction}

The coronavirus disease 2019 (COVID-19) is caused by the severe acute respiratory syndrome coronavirus-2 (SARS-CoV-2) and has rapidly spread around the globe, emerging as a significant threat worldwide [1]. Although evidence on the pathophysiology of COVID-19 is rapidly growing, underlying pathological mechanisms which cause some patients to get seriously sick while others experience mild symptoms, remains hitherto unexplained. Understanding the underlying pathological mechanisms of the clinical features of the disease will increase the efficacy of management strategies and subsequently prevent many fatal outcomes.

Herein provided, is a comprehensive view of different pathological aspects of COVID-19, potentially influencing the vulnerable development of the disease.

Address for correspondence: Maciej M. Kowalik, MD, PhD, DSc, Department of Cardiac Anesthesiology, Medical University of Gdansk, ul. Smoluchowskiego 17, 80-217 Gdańsk, Poland, tel: +48 58584 4209, fax: +48 58584 4210, e-mail: mkowalik@gumed.edu.pl

Received: 4.05.2020 Accepted: 5.05.2020 


\section{The SARS-CoV-2 virus, its transmission and entry points}

At the beginning of December 2019, a new respiratory tract disease was diagnosed among residents in the city of Wuhan, Hubei province, China $[2,3]$. Yet unknown to that point, coronavirus $(\mathrm{CoV})$, was referred to initially as $2019-\mathrm{nCoV}$, and was identified as the causative agent [2]. The viral genome sequencing revealed a ca. $80 \%$ sequence identity with the SARS-CoV virus, which caused the severe acute respiratory syndrome (SARS) outbreak in 2002 [3]. As a ribonucleic acid (RNA) virus it has a vast potential of mutating and generating sub-species or variants [4]. The SARS-CoV-2 virus was confirmed by real-time reverse transcription polymerase chain reaction (rRT-PCR) in sputum, saliva, nasal, pharyngeal and tracheal swabs, broncho-alveolar lavage, pleural effusion fluid, blood, feces, and occasionally in urine, and even semen [5-14]. According to World Health Organization (WHO), the detection of a single RNA sequence of coronavirus by rRT-PCR is uniform with the confirmation of the disease. To date, for instance, in Poland, two sequences are necessary [15].

The novel SARS-CoV-2 virus infection is mainly transmitted by micro-droplets generated in the airway of an infected person and ejected during cough, sneeze and ordinary talk $[16,17]$. The droplets, containing virions, can enter a host through the epithelial cells of the upper respiratory tract and conjunctiva [18]. The clinical and epidemiological importance of aerosol transmission remains under investigation [19]. However, the virus-containing aerosol may reside for hours in the air in insufficiently ventilated rooms and spaces. So, overcrowded waiting rooms endanger patients through the exposition to increased initial viral load [16]. Some authors claim that transmission of the virus from bats to humans occurred through the digestive system, with gastrointestinal symptoms observed as the first or accompanying presentation of the disease with a varied frequency, from 1 to $36 \%$ of patients [14]. Additionally, as the virus can survive on a variety of surfaces for a surprising length of time, and its infective potential from this source remains unstudied [16]. If so, the transmission through ingestion cannot be ignored. However, the most difficult epidemiological challenge in COVID-19 is a period that lasts for several days of pre-symptomatic replication and shedding of SARS-CoV-2 [20].

The virus uses a double-domain glycoprotein on its surface (S1), which has a high affinity to angiotensin-converting enzyme type 2 (ACE2) receptors, to invade cells $[2,3,21]$. Viral entry is enabled through the promotion of $\mathrm{S} 1$ by hosts transmembrane protease serine 2 (TMPRSS2) and endosomal cysteine proteases cathepsin $\mathrm{B}$ and $\mathrm{L}$ $[18,22]$. Expression of the ACE2 gene may differ between populations, thus explaining some geographical differences in COVID-19 severity [23]. Interestingly, a combination of inhibitors of both proteases blocked the virus entry in vivo effectively [22]. Given the vast representation of the receptors as mentioned above in human tissues, the virus itself has a broad capacity to infect various human cell types and induce different pathogenic chains of events that correspond with a variety of clinical pictures of COVID-19 [14, 24, 25]. Viral replication begins in the ciliated epithelium of the nasal cavity with the highest expression of its receptors in the goblet/secretory cells and the highest virus yield found in nasal swabs $[18,24]$. Down the airway, the next target of the virus and the site of its replication with critical pathogenic implications is the lower respiratory tract and pneumocytes [7].

\section{The virus versus the immune system}

Viral pathogenicity depends on its ability to overcome the host's protective mechanisms of innate immunity. Innate immunity consists of natural barriers and nonspecific immune responses. The viral armor - its virulence - includes a variety of tricks. The host's age and the virus adaptation add to the final seriousness of the disease in rats [26]. One missense mutation and a resulting single amino acid change in the S1 domain of the spike protein, has increased its affinity to the ACE2 receptor. As a result, adult rats became susceptible and developed full picture of SARS, the young still not showing clinical signs [26]. This experiment is a warning for all of those who postulate isolation and social distancing only for the elder, more vulnerable members of the society. More so, as SARS-CoV-2 differs from SARS with just a small sequence in the spike protein [27].

A molecular signature of any intruder in the respiratory system is checked on the surface of respiratory epithelium, interposed dendritic cells and tissue macrophages by means of toll-like receptors, belonging to the superfamily of pattern recognition receptors. The second control point is located inside the cells. MDA-5 and RIG-I receptors, which are present in the cytosol, sense, e.g., 5 'triphosphate RNA or double-strand RNA - the specific by-products of viral replication. At the same time, host RNA is protected from recognition 
by a polypeptide cap on a 5 'end. Upon recognition, interferons and other cytokines are secreted and are sent to the nucleus which signals to promote transcription of the proteins necessary to combat the intruder. The signaling relies upon biochemical reactions of phosphorylation and ubiquitination. Below, are mentioned some protective mechanisms that have been found in coronaviruses, as viral self-defense seems to be family specific. The strategies have been thoroughly described in an excellent review by Kikkert [28].

Viruses replicate in cytosol. Once there, they try to escape recognition through the enclosure of genetic material within capsules made of viral proteins and intracellular membranes $(\mathrm{CoV}$ proteins nsp3 and nsp4). Secondly, viral enzymes (e.g. CoV nsp16), are used to synthesize a cap which closely resembles the one, located at human RNA terminus and hiding its 5 'end. It seems that during the infective cycle, the virus may auto divide its own RNA to avoid recognition. The SARS-CoV N protein was found presumably to pack the viral RNA, thereby protecting them from degradation [28]. Apart from passive protection, viruses can actively switch-off host defense. Disruption of the transcription and translation inside the infected cells has been confirmed for SARS-CoV and middle-east respiratory syndrome (MERS)-CoV. Viruses interact with the formation of stress granules, containing untranslated mRNAs and serving as part of an antiviral response [29]. Ubiquitin-dependent regulatory processes in the cells, including activation of interferons, get disrupted upon viral infection due to the destruction of ubiquitin chains by viral proteases. Mechanisms which serve to avoid innate immunity are the virus license for survival and replication. Not surprisingly, SARS-CoV which utilizes almost all recognized methods, is so pathogenic. The innate immunity mechanisms weaken in advanced age, which adds to the vulnerability of the older population in the context of viral infections.

\section{Why are elderly patients getting so sick?}

In fully competent subjects, dendritic cells and macrophages activated by cytokines, present viral antigens to the lymphocytes to recognize and destroy the virus. Anti-viral specific T cells, mainly CD8+ cytotoxic $T$ cells, eliminate the infected cells. CD $4+\mathrm{T}$ cells instruct $\mathrm{B}$ cells to produce specific antibodies that stop the spread of viral particles in body fluids. These mechanisms allow for containment of the infection within the lungs, viral clearance, and restitution of the damaged tissues.
In patients with the burden of immunosenescence, the exaggerated inflammation does not induce a sufficient response of the lymphocytes, and the infection spreads further. The role of the immune system loses primary significance and non-immune factors related to necrosis of the tissues and decompensated circulation and ventilation become more important. However, persistent inflammation may still be responsible for opening entry gates for eventual bacterial infections and generalization of the changes into multiorgan failure and death [30]. This is probably the case of frail elderly but also younger subjects with similar deficiencies [31].

Aging of the immune system has common features present in all subjects, such as reduced production of $\mathrm{T}$ cells due to thymic atrophy, increased number of memory lymphocytes at the periphery and increased levels of serum proinflammatory cytokines [32]. Environmental factors can exaggerate these features into a level which is a danger to survival. For example, so-called immune risk phenotype (IRP) is never seen in centenarians as its burden does not allow the elderly to fight effectively with infections, and they die earlier [33, 34]. Although many environmental factors affect the immune system, some of them notoriously deteriorate immunity (Table 1 ). These are mainly intracellular pathogens responsible for asymptomatic chronic infections such as the Herpesviridae family (with cytomegaly virus [CMV] in the first place) or Chlamydia sp. When infected with these

Table 1. Risk factors of the immune risk phenotype.

\begin{tabular}{l}
\hline Immune factors \\
\hline Expanded clones of CD8+ T cells (CD8+CD28-), \\
CD8 T oligoclonality \\
Reduced percentage and number of CD4+ T cells \\
Decreased CD4/CD8 index \\
Inflammageing - high level of proinflammatory \\
cytokines, like interleukin 6 \\
Monocytosis with M1 monocytes \\
Cytomegaly virus positivity \\
\hline Clinical factors \\
\hline Atherosclerosis-related diseases \\
Inflammatory/autoimmune chronic diseases \\
including late-onset asthma, chronic obstructive \\
pulmonary disease, and pulmonary fibrosis \\
Diabetes and obesity \\
Neurodegeneration \\
History of non-responsiveness to vaccination \\
(for example: flu)
\end{tabular}


pathogens, the subject cannot eradicate them but only control a possible progression of the infection. It is a lifelong game in which immunocompetent cells keep the pathogens dormant for as long as possible. Unfortunately, there is a price to pay for keeping the infections asymptomatic because long subclinical activation of the immune system creates its 'attrition' [35]. CD8 + T cells, the main cytotoxic subset responsible for clearance of the body from intracellular pathogens like viruses, proliferate and expand into big clones that occupy the immune space in the peripheral immune system. Unfortunately, these expanded clones, often marked as CD8 + CD28- T cells, are anergic. They no longer respond to any pathogen and, at the same time, occupy immune space in the peripheral lymphoid system which hampers the generation of immune responses mediated by naïve $\mathrm{CD} 8 \mathrm{~T}$ cells and thus, influencing health status. For instance, it is an important cause for unresponsiveness to flu vaccines of the elderly [36]. Laboratory testing can be extremely precise here as was found herein, that the proper immune response occurs until the level of functional $\mathrm{CD} 8+\mathrm{T}$ cells specific to $\mathrm{CMV}-$ phenotype $\mathrm{CD} 8+\mathrm{CD} 28+$ antiCMV + - is at least three cells per $\mu \mathrm{L}$ of peripheral blood [37]. Also, for this reason, the popular expectation that an anti-SARS-CoV-2 vaccine will become a game-changer in the fight against the COVID-19 pandemic, may become a disappointment, particularly in the elderly.

As clinical symptoms in COVID-19 suggest an uncontrolled immune response, a deeper insight into the features of immunosenescence may help to understand the pathogenesis of COVID-19 and reveal immune biomarkers identifying those at highest risk of fatal complications. Importantly, immunosenescence does not affect only the elderly. The immune system of younger subjects affected by the burden of chronic diseases undergoes similar changes very often. The theory presented above can serve as one of the possible explanations of the fact that young patients can also suffer fatality from COVID-19 [38].

Immunosenescence also affects $\mathrm{CD} 4+\mathrm{T}$ cells. A reduced number of these cells is responsible for severe immunodeficiencies, as in human immunodeficiency virus (HIV) infection. Together with a high proportion of CD4+CD28- T cells this can be observed in the elderly and is associated with anergy of the immune system [31]. The changes within this subset are less related to chronic infections and correlate rather with the presence of chronic non-communicable diseases with some inflammatory background, such as rheu- matoid diseases, diabetes, atherosclerosis, and neurodegeneration [34]. Immunosenescence and inflammation within the lymphoid compartment are counteracted by an increased level of antiinflammatory CD4+FoxP3 $+\mathrm{T}$ regulatory cells, which accumulate with age. Nevertheless, they are only effective in some subjects as in the majority of the elderly, the function of $\mathrm{T}$ regulatory cells is impaired, and even the higher numbers do not compensate for this impairment [39]. Altogether, decreased $\mathrm{CD} 4 / \mathrm{CD} 8$ ratio with confirmed CD28expansions and reduced absolute number of $\mathrm{CD} 4+$ $\mathrm{T}$ cells is an important feature of IRP, which can be used to identify those at high risk of COVID-19 [40]. Indeed, a recent report on the immune phenotype in 60 patients from Wuhan confirmed the majority of this characteristic as predictive factors. Patients who developed severe COVID-19 were characterized by lymphopenia and significantly reduced numbers of both $\mathrm{CD} 4+$ and $\mathrm{CD} 8+\mathrm{T}$ cells in peripheral blood. Importantly, the recovery was associated with an increasing number of CD8+ $\mathrm{T}$ cells during the therapy. In contrast, the level of those cells in non-responders to the therapy did not change or even decreased [40].

\section{The COVID-19 lung pathology}

Initially, the COVID-19 disease begins with symptoms of mild respiratory tract infection - fever, cough, and fatigue [41]. While most commonly COVID-19 patients present with relatively mild viral pneumonia, some of them, for a reason not completely understood, progress to acute respiratory distress syndrome (ARDS) with profound hypoxia [42]. Indeed, SARS-CoV (the one responsible for previous SARS epidemic) particles ORF8b and viroporin 3a induce endoplasmic reticulum stress, lysosomal damage, and cell death of pneumocytes and robustly activate NLRP3 inflammasome - the innate system of pathogen recognition in macrophages [43]. The inflammasome formation results in the secretion of proinflammatory cytokines [44]. Unfortunately, viral particles switch on the apoptosis of macrophages, too. The consequences of this recognition depend on the immune background of the patient. If the patient is affected by an IRP and inflammaging, the secretion of proinflammatory cytokines may quickly increase beyond the regulated levels, and the process of ARDS is launched [32]. The accumulation of anergic lymphocytes that express memory phenotype is a big source of proinflammatory cytokines, like interleukin 1 (IL1), IL6, tumor necrosis factor alpha. 
The cytokine storm, which is observed between $7^{\text {th }}$ to $10^{\text {th }}$ day in some fulminant COVID-19 cases is likely explained through antibody-dependent enhancement of the inflammatory reaction, well described in Dengue infection [45-47]. Formation of immune complexes containing SARS$\mathrm{CoV}-2$ and non-neutralizing antibodies leads to a life-threatening inflammatory response [45, 46]. These complexes, by binding to the Fc receptor for immunoglobulin (Ig), enable SARS-CoV-2 to enter and replicate in new, non-pneumocyte, target cells: antigen-presenting dendritic cells and macrophages. The time relationship between the formation of the first antibodies and the dramatic acceleration of the initially mild inflammatory lung destruction can be noticed around the $7^{\text {th }}-10^{\text {th }}$ day of symptomatic COVID-19 [47]. Interestingly, on average $5 \%$ of convalescents have completely undetectable antibodies against SARS-CoV-2, suggesting that perhaps rapid - other than humoral - immune responses might be crucial for viral clearance and recovery [48].

Indeed, increased levels of these cytokines belong to the strong predictors of frailty in the elderly, and this feature of immunosenescence is often called inflammageing [49, 50]. Lymphocytes probably prime the ignition of inflammageing. Other potent producers of proinflammatory cytokines include innate immune cells, such as monocytes and macrophages, and non-immune cells, such as adipocytes. The latter, together with adiposelymphoid tissue crosstalk, obesity, and diabetes are beyond the scope of the present discussion. Nevertheless, as an extremely important source of inflammation, they should not be forgotten [51]. Healthy aging tends to limit the inflammation with increasing levels of anti-inflammatory CD14+CD16+ M2 monocytes/macrophages, which spread throughout the tissues [52]. On the other side, classical CD14+ + CD16-M1 monocytes/macrophages accumulate preferentially within damaged tissues such as arterial walls with atherotic plaques where they escape the regulation by $\mathrm{M} 2$ cells and CD4+FoxP3+ T regulatory cells. M1 cells excrete proinflammatory factors and the phenotype itself is significantly linked with atherosclerotic/inflammatory/diabetes age-associated diseases [53, 54]. For these reasons, increased levels of activated monocytes, notably M1 phenotype, and high levels of proinflammatory cytokines, mainly notorious IL6, are also important features of IRP. Moreover, inherited higher IL6 levels in serum were reported and associated with a higher risk of atherosclerosis and complications after hematopoietic stem cell transplantation $[55,56]$. High level of proinflammatory cytokines from different sources in frail elderly people narrows the margin where their effects are only local and can be accommodated by mechanisms of the body homeostasis. Hence, a sudden increase in their level provoked by systemic stimuli, like a generalized viral disease, bacteremia, massive inflammation on the mucosal surface (pneumonia) or sepsis, may easily escape the regulation and trigger systemic responses within the definition of 'cytokine storm', systemic inflammatory response syndrome (SIRS) or ARDS [57].

The cytokines increase the permeability of endothelium and increase the adhesion of immune cells to vessel walls through the expression of selectins and integrins induced on the endothelial surface, while nitric oxide and prostacyclin also produced by activated macrophages trigger relaxation of media smooth muscles and vasodilatation [58]. The fluid leaking through the vessel walls accumulate in the pulmonary parenchyma but also leak through damaged pneumocytes to the pulmonary alveoli. Mucous secretion is stimulated and soon the alveoli and bronchial tree are flooded. Dying macrophages, pneumocytes and the endothelium are abundant sources of tissue factor. Thus, the extrinsic pathway of coagulation is activated in plasma throughout the pulmonary vasculature, resulting in the clinical picture of local coagulation [59]. Obstruction of pulmonary capillaries by thrombi and local inflammatory vasodilation contributes to veno-arterial shunt and profound hypoxia observed in the severe COVID-19 patients $[15,42,59,60]$. The process is limited by the immune status of the patient as the mechanisms described above accelerate into vicious positive feedback loops. The role of downregulating the antiinflammatory effect of ACE2 by SARS-CoV-2 was recently described in an excellent review by Huang et al. [61]. For example, macrophages are activated by thrombin and further activate coagulation, or activated endothelium attracts immune cells and immune cells adhered to its surface further increases the activation of endothelial cells.

\section{Coagulation and thrombosis in COVID-19}

Initial reports from China, reported patients suffering from a severe or fatal COVID-19 disease course, with slightly lower platelet count and a higher level of d-dimer [41, 62]. But it was the first reports from Italy and other European countries, which emphasized the remarkably high incidence of pulmonary embolism and thrombosis in the most severe and fatal cases [59, 60, 63]. At 
present, there is an awareness of a few clinical and laboratory features of patients with COVID-19, which is thrombocytopenia, elevated d-dimer level, prothrombin time prolongation and disseminated intravascular coagulation $[64,65]$. The International Society of Thrombosis and Hemostasis (ISTH) recommends prothrombin time, platelet, fibrinogen and d-dimer to determine prognosis and identify patients requiring admission to hospital [65]. The rise of d-dimer, seen in the majority of patients with confirmed COVID-19, may be due to the fibrinolytic processes and subsequent spillover into the bloodstream $[66,67]$. The hypercoagulable state can be explained by systemic inflammatory response alone, resulting in both massive activation of coagulative pathways, and at the same time, inhibition of fibrinolysis, which may be caused by up-regulation of PAI1 gene [64]. Coagulation disorders are correlated with the severity of bacterial and viral infections [68]. But they can be triggered through systemic or local inflammation involving the endothelium, platelets, and plasma factors [69, 70]. Also, in COVID-19 endothelial dysfunction, high von Willebrand factor activity, and probably genetic factors play an essential role in the process. Age and diabetes have been reported risk factors of a fatal outcome from COVID-19, but they are also well-known risk factors for deep venous thrombosis [41, 71, 72]. Moreover, there are confirmed genetic determinants of deep venous throbosis. Inherited protein C, S, von Willebrand factor, and antithrombin deficiencies include specific single nucleotide polymorphisms and haplotypes [73-79]. The role of inherited thrombophilic disorders in the risk of severe COVID-19 has not as yet been emphasized or investigated to date.

Klok et al. [60] reviewed 184 patients with COVID-19 admitted to an intensive care unit (ICU), of whom $31 \%$ experienced thrombotic events - particularly pulmonary embolism [80]. Surprisingly, the majority of infected individuals remained resistant to high doses of both lowmolecular-weight heparin (LMWH) and unfractionated heparin (UFH) [60]. Although it was speculated that it might result from a decreased antithrombin level, it appears that the failure to achieve therapeutic prolongation of activated partial thromboplastin time results from abnormally high levels of factor VIII [81]. Bleeding disorders reported in COVID-19 patients are surprisingly rare - approximately $2 \%$ of cases - and present mostly with mild petechiae due to depletion of platelet [82]. However, the common coagulopathy in severe COVID-19 seems to be local pulmonary thrombosis, a vast portion of ICU patients develop a systemic disseminated intravascular coagulation (71.4\% of non-survivors vs. $0.6 \%$ of survivors), though it may still be a systemic picture of massive local endothelial injury during ARDS development $[62,83,84]$. Nevertheless, the first reports are available, which document the beneficial effect of heparin use on the outcome from COVID-19 [83]. The present report considers that to achieve proper anticoagulation, agents that target either thrombin directly or factor Xa may be regarded as an alternative if high-dose LMWH or UFH appears ineffective. Also of note, less interest has been paid, so far, to antiplatelet therapy in COVID-19, with acetylsalicylic acid in front of it. Also, tissue plasminogen activator was already considered as an eventual adjunct therapy in severe COVID-19 patients with severe ARDS [85].

Interestingly, there have been reports of transient anticardiolipin IgA, anti-B2-glycoprotein IgA, and IgG antibodies presence (commonly associated with antiphospholipid syndrome) in three COVID-19 positive patients admitted to ICU. All of them developed complex coagulopathy and ARDS, with evidence of ischemia in physical examination. One of them experienced multiple cerebral infarcts [86]. Therefore, it is also hypothesized that the occurrence of nonspecific neurologic symptoms reported in some COVID-19 patients may be explained through disseminated intravascular coagulation and micro-emboli in the brain $[62,87,88]$.

\section{COVID-19 as a systemic disease - the clinical staging}

COVID-19 has been classified as an acute respiratory infection with a possibility of progression to respiratory insufficiency, multiorgan failure, and ultimately death. Mortality in COVID-19 increases steeply in the elderly being notoriously high in those 80 years old and older [41, 89, 90]. It has been universally accepted to stage the seriousness of COVID-19, according to Modified Early Warning Score (MEWS), based on clinical parameters: frequency of breath, pulse rate, systolic arterial pressure, hourly diuresis, body temperature and the state of consciousness [91]. Points from 1 to 3 are attributed to the positive or negative deviation of each parameter from the baseline and summated, giving the total score. Hospitalization is required for each patient presenting with dyspnea and/or radiologic signs of pneumonia (stage 2 and above). MEWS equal to and above three and/or $\mathrm{SpO}_{2}$ 90-92\% are symptomatic for severe pneumonia 
(stage 3), the patient needs continuous monitoring of vital parameters and the risk of the organ failure is increased. Patients in the fourth stage of the disease suffer at least from acute respiratory distress syndrome with $\mathrm{paO}_{2} / \mathrm{FiO}_{2}$ ratio below $300 \mathrm{mmHg}$ and require respiratory support within the intensive therapy facilities [15, 92].

\section{Acute kidney injury in COVID-19}

Up to $30 \%$ of patients with COVID-19 admitted to an ICU presented with symptoms of acute kidney injury (AKI), advanced to stage 3 , according to the 2012 Kidney Disease: Improving Global Outcomes (KDIGO) [93, 94]. Wang et al. [12] denies AKI being caused directly by the SARS-CoV-2 virus. However, renal podocytes and proximal tubule cells express both of the viral receptors - ACE2 and TMPRSS2, serving as a target for it [12, 23]. Virus particles were identified in podocytes and proximal tubular epithelium on autopsy [95]. Prominent acute proximal tubule injury was observed, which manifested itself as the loss of brush border, vacuolar degeneration, dilatation of the tubular lumen with cellular debris, and occasionally even frank necrosis and detachment of epithelium with the bared tubular basement membrane [95]. Glomerular thrombosis, fibrin sediments or platelet aggregates were not observed, suggesting that local thrombosis had not been triggered [95]. Intensivists from the United Kingdom suggested a careful water balance assessment in patients with COVID-19 ARDS on admission to ICU, as apart from the heavy lung injury, they frequently presented with dehydration and even hypovolemia. Combined with "keep the lung dry" rule for ARDS therapy, this led to increased AKI prevalence.

\section{COVID-19 in the cardiovascular system}

Although cardiovascular comorbidities seem to be a key threat in patients with COVID-19, thus far, the underlying mechanisms remain unknown. Preceding coronavirus outbreaks essentially involved the cardiovascular system by causing complications, i.e. hypotension, arrhythmias, myocarditis, etc. [96, 97]. COVID-19 infection seems to have comparable cardiac manifestations. The infection with SARS-CoV-2 is associated with cardiac dysfunction as well as arrhythmias and the nature of the myocardial injury appears to be serious in the COVID-19 subset (Fig. 1) [98].

First and foremost, several groups reported that many patients with COVID-19 were diagnosed as hav- ing an acute myocardial injury, manifested mainly by elevated levels of high-sensitive troponin. For instance, an increase in high-sensitivity cardiac troponin I levels $(>28 \mathrm{pg} / \mathrm{mL}$ ) occurred in 5 of the first 41 patients diagnosed with COVID-19 in Wuhan, 4 of them were admitted to ICU [99]. Shi et al. [100] reported 57 fatal outcomes of which $10.6 \%$ had coronary artery disease, 4.1\% had heart failure, and 5.3\% had cerebrovascular disease. Similarly, Guo et al. [98] reported that myocardial injury is significantly associated with fatal outcome of COVID-19.

Non-coronary, direct myocardial injury via dysregulation of ACE2 is most likely the cause [61]. SARS-CoV-2 enter cells to trigger infection by using ACE2, facilitating virus entry into lung alveolar epithelial cells. Of note, ACE2 is also highly expressed in the human heart, vascular cells, pericytes, kidneys and gastrointestinal tract [101-103]. Thus, it is almost certain that acute cardiovascular complications are not secondary to lung disease. Although it was hypothesized that the treatment strategy based on the usage of the renin-angiotensin-system inhibitors, i.e., ACE inhibitors or angiotensin receptor blockers (ARBs) may promote SARS-CoV-2 binding to ACE2, large body of evidence does not confirm these concerns [104-107]. Notably, in preclinical studies, ARBs appeared to have a potentially protective effect [108]. SARS-CoV-2 may also enter cells through the CD209 receptor, expressed in macrophages, and promoting virus invasion into immune cells in cardiac and vascular tissues [109].

Alternative mechanisms of myocardial injury comprise the cytokine storm, hypoxia-induced excessive intracellular calcium leading to cardiac myocyte apoptosis [106, 110, 111]. Cardiac injury activates the innate immune response and releases proinflammatory cytokines. Since autopsy revealed interstitial mononuclear inflammatory infiltrates in the heart tissue, inflammation could be one of the potential mechanisms of acute myocarditis, ischemia and heart failure in the COVID-19 setting [112]. In these cases, arrhythmias might be associated with infection-related myocarditis which appears several days after the initiation of fever [113]. The virus-mediated lysis of cardiomyocytes is usually followed by a T-cell response and further myocardial injury and heart failure [114].

Since endothelial cell involvement has been recognized across different vascular beds, endothelial dysfunction may substantially contribute to the pathomechanism of COVID-19. Of note, ACE2 receptors were also found on the endothelial cells and, in the in vitro study, SARS-CoV-2 directly infected human blood vessel organoids [115]. 


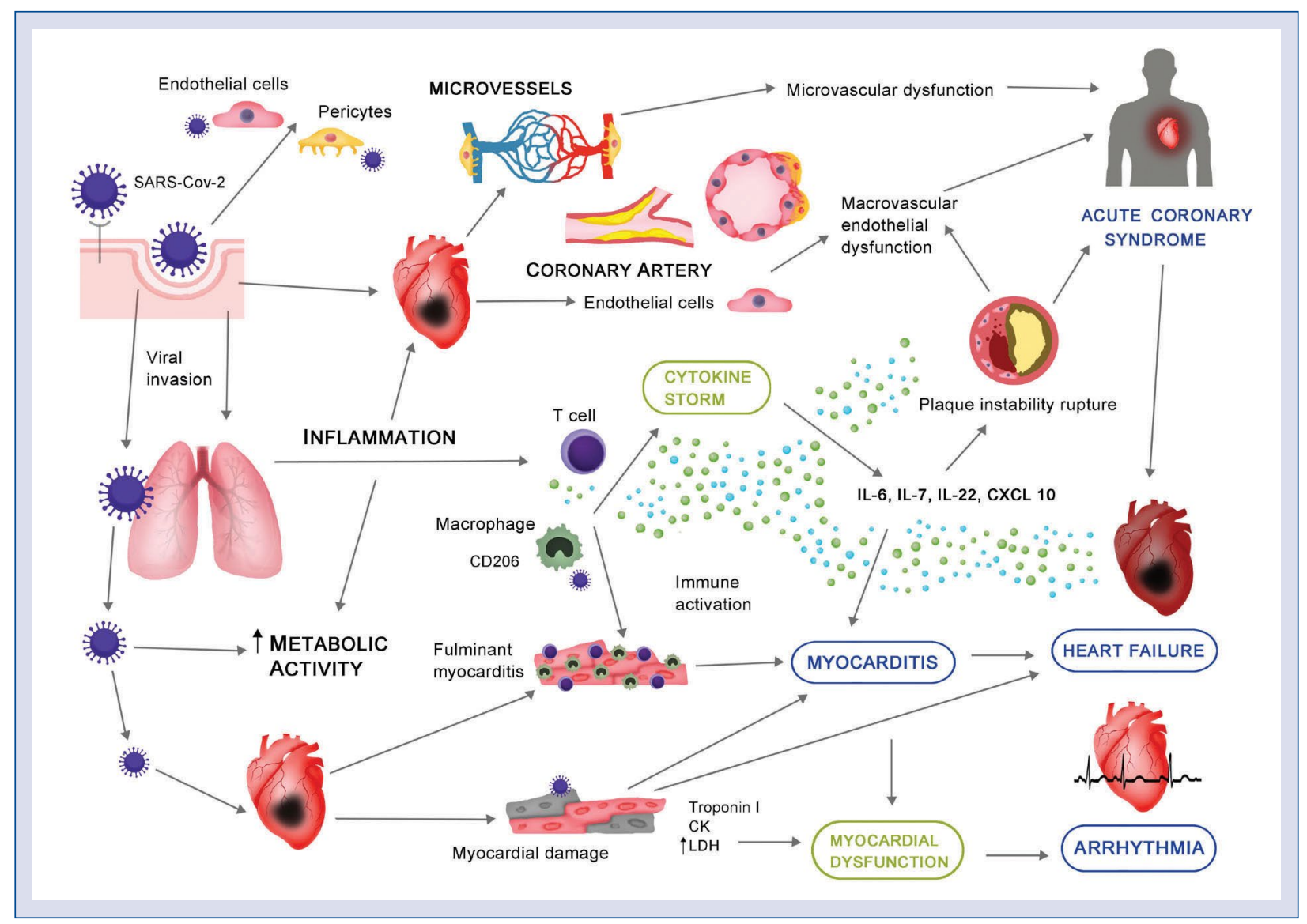

Figure 1. COVID-19 and the cardiovascular system. Severe acute respiratory syndrome coronavirus-2 (SARS-CoV-2) enters host cells activating inflammation processes, and, subsequently, multiorgan failure. Severe micro- and macrovascular dysfunction, as well as proinflammatory processes, may lead to plaque instability and, consequently, the development of acute coronary syndrome. Infection of the respiratory tract activates a 'cytokine storm' and subsequently $T$ cells/macrophages infiltrating myocardium and resulting in myocarditis and cardiac damage. Additionally, SARS-CoV-2 invades cardiac myocytes directly, causing myocardial dysfunction and further complications, i.e., acute heart failure and/or arrhythmias; CK — creatinine kinase; IL — interleukin; LDH — lactate dehydrogenase.

Injured endothelium, with histological signs of inflammatory infiltration, evidence of endothelial and inflammatory cell death, were present in different human organs including heart, the small intestine, lung, kidney, and liver [116]. In 1 case, myocardial infarction was reported with no sign of lymphocytic myocarditis [116]. Endothelial dysfunction might be caused by direct infection and an inflammatory response, finally leading to microvascular dysfunction, organ ischemia, inflammation and subsequently to apoptosis [116, 117]. In summary, endothelial dysfunction, cytokine storm, oxidative stress, as well as upregulation of angiotensin-II may essentially explain the coagulopathy seen in severe COVID-19 patients [118]. Last but not least, since hypercoagulability and systemic inflammatory activity can persist, COVID-19 infection may influence long-term outcomes [119]. Although, to date, no long-term outcome measure is known, a history of SARS-coronavirus infection is associated with cardiovascular comorbidities, including, for instance, glucose metabolism disorders [97]. Inflammatory mechanisms and activation of immune responses underlie a broad range of cardiovascular diseases including atherosclerosis, heart failure or hypertension $[55,120]$. Importantly, generalized endothelitis and subsequent microcirculatory dysfunction, which is observed in many local vascular beds in COVID-19 patients, and might be an interesting target for treatment strategies, especially in high-risk vulnerable patients.

\section{Therapeutic options}

COVID-19 is an infectious disease, which has direct pharmacological implications. According to 


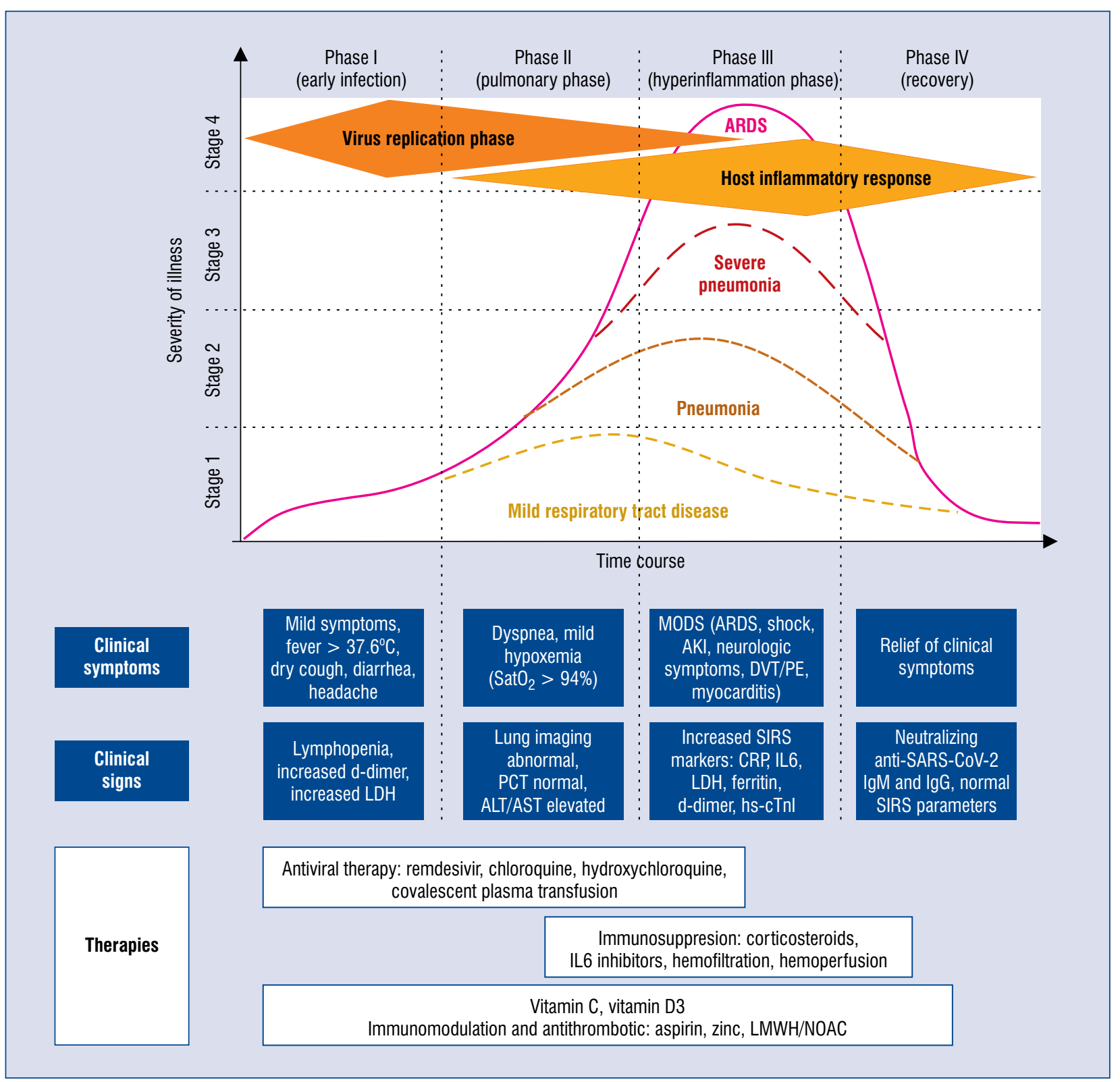

Figure 2. Phases and severity grading of COVID-19 - after Siddiqi and Mehra [47], modified. During early infection virus replication and shedding is rapidly accelerating within the first 4-10 days (Phase I). Together with the cytopathic effect of the virus replication clinical symptoms occur and the first immunological mechanisms are triggered (Phase II). With an occurrence of the first non-neutralizing antibodies, antibody-dependent augmentation of inflammation occurs, which together with local thrombosis and sepsis leads to multiple organ failure (MODS), acute respiratory distress syndrome (ARDS), acute kidney injury (AKI) and deep venous thrombosis (DVT) and pulmonary embolism (PE). COVID-19 may present with four stages of severity, either as a mild respiratory tract infection, viral pneumonia, severe pneumonia, or ARDS; ALT — alanine aminotransferase; AST — aspartate aminotransferase; CRP — C-reactive protein; hs-cTnl — high-sensitivity cardiac troponin I; Ig — immunoglobulin; IL — interleukin; LDH — lactate dehydrogenase; LMWH — low-molecular-weight heparin; NOAC — non-vitamin K antagonist oral anticoagulant; PCT - procalcitonin; SARS-CoV-2 - severe acute respiratory syndrome coronavirus-2; SIRS — systemic inflammatory response syndrome.

the basic knowledge, its natural history can be divided into four stages - early infection, pulmonary phase, hyperinflammation, and recovery (Fig. 2) [47]. Before a definite solution for COVID-19 treat- ment is found, the efforts of the scientific community are dual. The first path is directed against the SARS$-\mathrm{CoV}-2$ virus itself. There is a need to determine which of the antiviral agents that have already been 
synthesized and tested through the first and second phase of approval, which prove sufficiently effective to block the virus entry and/or stop or slow down its multiplication to gain time for the innate and adapted reaction of the whole immune system. Within this approach, a list of agents have already been tested, including the combination of chloroquine or hydroxychloroquine with azithromycin, oseltamivir, lopinavir/ritonavir, darunavir, favipiravir, remdesivir, and ivermectin [15, 121-124]. With different, either unspecific or targeted mechanisms of action, each of them had been successfully used against other viruses or parasites. However, up to the date of completion of this manuscript, only chloroquine in Poland and remdesivir in the United States, have gained recommendation as the first-line treatment against COVID-19 [15, 125].

It is obvious that the success of direct antiviral treatment relies upon its application during the phase of viral entry and replication. The main fault of many clinical trials of antiviral agents lies in the fact that the treatment, for a variety of reasons, begins too late. First symptoms and/or signs of pneumonia, which often trigger the inclusion of the patient into a clinical trial can appear as late as 15 to 20 days after infection [47]. It should not be overlooked that such an approach, although safer from an insurance point of view, can leave us without appropriate and targeted treatment for many years on. For example, chloroquine has already been proven to reduce the viral load in vitro and early observations on its usefulness in vivo have been enthusiastic [124]. Later on, contrary results appeared in France [122]. Moreover, the arrhythmogenic properties have resulted in numerous interactions which make its safety questionable [122]. Currently, results of clinical trials of chloroquine are eagerly awaited, 23 of which are registered in China. Also, when it comes to WHO recommendations of chloroquine, ethical, and political considerations come into view. As it is the basic antimalarial drug, worldwide shortages could easily occur, rendering the huge and vulnerable population devoid of a cheap and easy cure [124]. Among direct antiviral agents, remdesivir seems to be the most promising one at the moment. Other options are still emerging, as screening for their possible targets and drug compositions is currently enhanced by high output computational analysis, modeling, and artificial intelligence tools [126].

Unfortunately, in the meantime too many victims of the viral attack get too seriously ill. So, in parallel, alternative paths of effective supportive treatment for all those patients must be created, and in whom the virus has successfully evaded the forces of their immunity. It would be an inappropriate waste of time if we did not take advantage of the accumulated knowledge on the pathogenesis of a variety of viral diseases, observe, make analogies, and draw conclusions. COVID-19 is not an entirely new disease. The closest relatives are SARS and MERS, and the stages of the disease resemble already known syndromes [27, 47]. Nonetheless, a timely prediction of the subsequent events and appropriate choices and timing of the intervention still pose the main challenges of supportive treatment. Curbing or modifying the inflammation phase requires a detailed understanding of the processes that take place down to the molecular signal levels. Antiviral therapies often prove ineffective in late phases of viral diseases, as they are more loosely linked to the viral presence. The phenomena which are observed in the advanced stages of COVID-19 are rather due to the insufficient, over-induced, or dysregulated response of the immune system and its counterparts in the human body, the most important of them being the coagulation system. If the damage of the infected cells, caused by the pathogen, is profound enough, even elimination of the virus may not protect people against the consequences of the primary infection. At this point, it is worth remembering that in COVID-19, as well as with other viral diseases, the response of the body depends on the viral load [127].

The supportive treatment can be initiated as early as the appearance of the first symptoms of the disease and perhaps even earlier, once the infected person tests positive. Hospital physicians may easily neglect the prehospital, but in the natural course of viral diseases, it may play an important role. Which interventions can be based on the pathophysiology of viral infections and receive attention and recommendations from primary care physicians? Can early, prehospital prone positioning prevent respiratory deterioration? Vitamins (C, D3) and microelements (zinc, selenium) are key coenzymes and active centers of multiple enzymes within the immune system. Their anti-inflammatory and antioxidant properties play an important role in overall health. Is there enough evidence supporting additional supplementation? Which of the medicines available over the counter can be recommended and are there any that should be avoided?

Overwhelming dyspnea and rapid deterioration have become the most threatening symptoms of COVID-19, often promoting early hospitalization in fear of being overlooked. In the descriptions of the clinical picture of pulmonary involvement, 
a long-lasting period of progressive desaturation without overt dyspnea is often mentioned as a prodromal phase to fulminant respiratory insufficiency [42]. A question remains, whether a population-wide use of pulse oximetry, under the guidance of family physicians and/or with the aid of telehealth applications, provides an easy answer to this problem. Such an approach would possibly decrease the risk of contracting the infection or supplementary viral load during the consultation at the outpatient and/or inpatient department and provide timely help when necessary. Patients and staff protection from the unnecessary use of scarce hospital resources would also limit the overall burden of the disease.

The knowledge on the immunosenescence and IRP is probably most useful in the assessment of patients at risk of fatal COVID-19. Timely recognition of the cytokine storm at the beginning of a systemic response to the virus through increased IL6 measurements, increases the probability of successful immunomodulatory treatment with anti-IL6 (tocilizumab) or general suppression with high dose corticosteroids or maneuvers to wash out cytokines, i.e., with hemofiltration [15, 128]. Moreover, identification through genotyping of the vulnerable population - i.e., carriers of the $I L 6$ proinflammatory mutations or deep venous thrombosis risk haplotypes, may be used for more patient-tailored therapies. Nevertheless, one should remember that high levels of IL6 last for several hours only, and then SIRS changes into compensatory anti-inflammatory response syndrome with prevalent suppressive cytokines, like IL10 [32]. That being said, the suppression with antibodies against pro-inflammatory cytokines or glucocorticoids during the late phase might only deepen the problems. Hemofiltration is still a very unspecific method and may also devoid the body of many small regulatory molecules, either antiinflammatory or those necessary for homeostasis. As it has been described in the previous section, the cytokine crisis leads to excessive activation of the coagulation cascade, which must be appropriately addressed in therapy. Due to the lack of robust data, LMWH is still recommended, though it remains based on single, small group studies [62].

The summary of supportive intensive therapy treatment (oxygen therapy, methods of ventilation, extracorporeal membrane oxygenation, etc.) in patients with severe disease have recently been summarized and will not be repeated here [15, 129].

A special place among the currently approved treatments belongs to the application of convales- cent plasma $[15,130,131]$. Its potential is mixed and not yet definitely studied. The first possibility involves direct neutralization of the virus by the donor antibodies. The second includes immunoregulatory mechanisms. The plasma from COVID-19 survivors might be then very useful in immobilizing the virus but also attenuating antibody-dependent enhancement, similarly to intravenous IgG, which can potentially harness SIRS. The natural process of switching from the inflammatory to the resolution phase is the most difficult to study and understand. Clinically it is recognized by the fall of the body temperature, return of consciousness, normalization of vascular tone, and regaining of physical strength.

The question remains what happens at the cellular, biochemical, and molecular levels and how to support the body to limit its answer to recognition and elimination of the pathogen. The process has been extensively studied during the last 10 years and many of the biochemical signals involved have been identified [132]. The synthesis of specialized pro-resolving mediators (SPMs) requires substrates, biochemical energy and triggering [133]. The substrates are derived from the essential fatty acids - eicosapentaenoic acid and docosahexaenoic acid. The mediators are clustered in families named resolvins, protectins, and maresins. Subfamilies are then attributed cardinal letters and numbers, e.g., resolvin D3 (RvD3). The molecules have been found in the human white blood cells as well as in a variety of tissues late in the inflammation phase. The concentration of resolvins in tissues increases along with the decrease of the levels of pro-inflammatory prostaglandins and leukotrienes. The process occurs physiologically, initiated along with the inflammatory cascade of prostaglandins and leukotrienes, but can also be triggered by external substances. One of the substances that can move the balance towards resolution of the inflammation is a wellknown acetylsalicylic acid - aspirin, and one of the induced resolvins is aspirin-triggered resolvin D3 (AT-RvD3). AT-RvD3 successfully limited inflammation in experimental models (murine peritonitis) and blocked transmigration of human leucocytes across epithelial cells. RvD3 has been shown to appear late in the resolution phase, promoting macrophages that clean apoptotic cells. The transition towards the anti-inflammatory phase is also confirmed by the reversal of concentrations of interleukins - increased IL10 and decreased IL6 [132]. In aging mice, decreased concentration of pro-resolving lipid derivatives 
has been linked to prolonged duration of an acute inflammatory state [134].

The above-mentioned acetylsalicylic acid, or aspirin, is one of the most ancient treatment options which demands closer attention. For a long time holding the first place in a basic set of drugs prescribed during most pyretic diseases of childhood, aspirin was dethroned by paracetamol when attributed to the potential of induction of the Rey disease. The recognition of its anticoagulant properties resulting from the interplay with platelet receptors has led to a triumphant comeback. Nowadays aspirin is the must-of-cardioprotection and the strongest holding preventive measure against most of the complications of atherosclerosis. However, the protective role of aspirin is not limited to its anti-aggregatory properties, as aspirin is one of the recognized triggers of resolvin synthesis [134]. It has been found that many of these SPMs play an important role in limiting inflammation in chronic airway diseases. SPMs take part in changing the activity of neutrophils and macrophages, regulate the function of different subsets of lymphocytes, including the promotion of B-cell differentiation and aid in the restriction of cytokine production. Protectin D1 has been shown to improve survival in a mouse model of lethal viral respiratory infection [135]. The lipid phase of the fluid accumulating in the alveoli during the resolution phase of ARDS contains a high concentration of docosahexaenoic acid-derived resolvin D3. It has been experimentally shown, that AT-RvD3 can promote the resolution of inflammation in the pulmonary epithelium in the course of acute lung injury [133]. Could COVID-19 patients benefit from replacing immunosuppression with aspirin? From the experimental and observational data, it seems possible that aspirin, through the induction of RvD3, can prevent the inflammatory hyperreaction known as the cytokine storm. Is it not high time to seriously reconsider the protective role of aspirin in the infective respiratory diseases of adulthood?

At the moment, in the absence of a vaccine or targeted therapy, the only available preventive methods are non-specific (testing and isolation, quarantine, protection of porta of entry, sanitary cordon, social distancing, etc.) - as if we have been moved back in time. Understanding even the tiniest details of the pathogenesis of viral infections, like interactions between viral proteins and receptors on human target cells, the broad complexity of the immune responses and the functioning of the labyrinth of the coagulation system - have profound practical consequences: scientific, clinical, epidemiological, and economic. If these pathogenetic puzzles had been arranged another way - the general scenario of this pandemic could have been completely different. Viral genomes can quite easily be manipulated, but desperately lacking is an understanding of how such changes can affect our lives in a broader perspective.

COVID-19 outbreak has dramatically exposed our weaknesses on the individual, scientific, and organizational levels. However, it has also given us a chance to rethink and test, how strong we are when our efforts unite. One of the first symptoms is a fact in which we can conclude this lesson, and that is an unprecedented global open access to high-quality knowledge and international exchange of clinical experience, organizational and technical know-how.

\section{Conflict of interest: None declared}

\section{References}

1. Smiatacz T. It didn't have to happen this way - what COVID-19 tells us about translational medicine. Eur J Transl Clin Med. 2020.

2. Wu F, Zhao Su, Yu B, et al. A new coronavirus associated with human respiratory disease in China. Nature. 2020; 579(7798): 265-269, doi: 10.1038/s41586-020-2008-3, indexed in Pubmed: 32015508.

3. Zhou P, Yang XL, Wang XG, et al. A pneumonia outbreak associated with a new coronavirus of probable bat origin. Nature. 2020; 579(7798): 270-273, doi: 10.1038/s41586-020-2012-7.

4. Wang $\mathrm{M}, \mathrm{Li} \mathrm{M}$, Ren $\mathrm{R}$, et al. International expansion of a novel SARS-CoV-2 mutant. J Virol. 2020, doi: 10.1101/2020.03.15.20035204.

5. Wang W, Xu Y, Gao R, et al. Detection of sars-cov-2 in different types of clinical specimens. JAMA. 2020 [Epub ahead of print], doi: 10.1001/jama.2020.3786, indexed in Pubmed: 32159775.

6. Lescure FX, Bouadma L, Nguven D, et al. Clinical and virological data of the first cases of COVID-19 in Europe: a case series. Lancet Infect Dis. 2020, doi: 10.1016/S1473-3099(20)30200-0, indexed in Pubmed: 32224310.

7. Yu F, Yan L, Wang N, et al. Quantitative detection and viral load analysis of sars-cov-2 in infected patients. Clin Infect Dis. 2020 [Epub ahead of print], doi: 10.1093/cid/ciaa345, indexed in Pubmed: 32221523.

8. Peng L, Liu J, Xu W, et al. SARS-CoV-2 can be detected in urine, blood, anal swabs, and oropharyngeal swabs specimens. J Med Virol. 2020 [Epub ahead of print], doi: 10.1002/jmv.25936, indexed in Pubmed: 32330305.

9. Paoli D, Pallotti F, Colangelo S, et al. Study of SARS-CoV-2 in semen and urine samples of a volunteer with positive naso-pharyngeal swab. J Endocrinol Invest. 2020 [Epub ahead of print], doi: 10.1007/s40618-020-01261-1, indexed in Pubmed: 32329026.

10. Kujawski STC. et al. COVID-19 Investigation Team. Clinical and virologic characteristics of the first 12 patients with coronavirus disease 2019 (COVID-19) in the United States. Nat Med. 2020 
[Epub ahead of print], doi: 10.1038/s41591-020-0877-5, indexed in Pubmed: 32327757.

11. Zheng S, Fan J, Yu F, et al. Viral load dynamics and disease severity in patients infected with SARS-CoV-2 in Zhejiang province, China, January-March 2020: retrospective cohort study. BMJ. 2020; 369: m1443, doi: 10.1136/bmj.m1443, indexed in Pubmed: 32317267.

12. Wang L, Li X, Chen H, et al. Coronavirus disease 19 infection does not result in acute kidney injury: an analysis of 116 hospitalized patients from Wuhan, China. Am J Nephrol. 2020: 1-6, doi: $10.1159 / 000507471$.

13. Fang Z, Zhang Yi, Hang C, et al. Comparisons of viral shedding time of SARS-CoV-2 of different samples in ICU and non-ICU patients. J Infect. 2020 [Epub ahead of print], doi: 10.1016/j. jinf.2020.03.013, indexed in Pubmed: 32209381.

14. Wong SH, Lui RNs, Sung JJy. Covid-19 and the digestive system. J Gastroenterol Hepatol. 2020; 35(5): 744-748, doi: 10.1111/ jgh.15047, indexed in Pubmed: 32215956.

15. Niżankowski R, Myśliwiec M, Szymański P et al. Zalecenia w COVID-19, Agencja Oceny Technologii Medycznych i Taryfikacji. Warsaw, 2020.

16. van Doremalen N, Bushmaker T, Morris DH, et al. Aerosol and Surface Stability of SARS-CoV-2 as Compared with SARS-CoV-1. N Engl J Med. 2020; 382(16): 1564-1567, doi: 10.1056/ NEJMc2004973, indexed in Pubmed: 32182409.

17. Anfinrud P, Stadnytskyi V, Bax CE, et al. Visualizing speechgenerated oral fluid droplets with laser light scattering. N Engl J Med. 2020 [Epub ahead of print], doi: 10.1056/NEJMc2007800, indexed in Pubmed: 32294341.

18. Sungnak W, Huang Ni, Bécavin C, et al. SARS-CoV-2 entry factors are highly expressed in nasal epithelial cells together with innate immune genes. Nat Med. 2020 [Epub ahead of print], doi: 10.1038/s41591-020-0868-6, indexed in Pubmed: 32327758.

19. He Xi, Lau EHY, Wu P, et al. Temporal dynamics in viral shedding and transmissibility of COVID-19. Nat Med. 2020 [Epub ahead of print], doi: 10.1038/s41591-020-0869-5, indexed in Pubmed: 32296168.

20. Wei WE, Li Z, Chiew CJ, et al. Presymptomatic transmission of SARS-CoV-2 - Singapore, January 23-March 16, 2020. MMWR Morb Mortal Wkly Rep. 2020; 69(14): 411-415, doi: 10.15585/ mmwr.mm6914e1, indexed in Pubmed: 32271722.

21. Li F. Structure, function, and evolution of coronavirus spike proteins. Annu Rev Virol. 2016; 3(1): 237-261, doi: 10.1146/annurev-virology-110615-042301, indexed in Pubmed: 27578435.

22. Hoffmann M, Kleine-Weber H, Schroeder S, et al. SARS-CoV-2 cell entry depends on ACE2 and TMPRSS2 and is blocked by a clinically proven protease inhibitor. Cell. 2020; 181(2): 271-280.e8, doi: 10.1016/j.cell.2020.02.052.

23. Pan XW, Xu Da, Zhang H, et al. Identification of a potential mechanism of acute kidney injury during the COVID-19 outbreak: a study based on single-cell transcriptome analysis. Intensive Care Med. 2020 [Epub ahead of print], doi: 10.1007/s00134-02006026-1, indexed in Pubmed: 32236644.

24. Zou L, Ruan F, Huang M, et al. SARS-CoV-2 Viral Load in Upper Respiratory Specimens of Infected Patients. N Engl J Med. 2020; 382(12): 1177-1179, doi: 10.1056/NEJMc2001737, indexed in Pubmed: 32074444.

25. Fried J, Ramasubbu K, Bhatt R, et al. The variety of cardiovascular presentations of COVID-19. Circulation. 2020, doi: 10.1161/ circulationaha.120.047164.
26. Nagata N, Iwata N, Hasegawa H, et al. Participation of both host and virus factors in induction of severe acute respiratory syndrome (SARS) in F344 rats infected with SARS coronavirus. J Virol. 2007; 81(4): 1848-1857, doi: 10.1128/JVI.01967-06, indexed in Pubmed: 17151094.

27. Petrosillo N, Viceconte G, Ergonul O, et al. COVID-19, SARS and MERS: are they closely related? Clin Microbiol Infect. 2020 [Epub ahead of print], doi: 10.1016/j.cmi.2020.03.026, indexed in Pubmed: 32234451.

28. Kikkert M. Innate immune evasion by human respiratory RNA viruses. J Innate Immun. 2020; 12(1): 4-20, doi: 10.1159/000503030, indexed in Pubmed: 31610541.

29. Gaete-Argel A, Márquez CL, Barriga GP, et al. Strategies for success. Viral infections and membraneless organelles. Front Cell Infect Microbiol. 2019; 9: 336, doi: 10.3389/fcimb.2019.00336, indexed in Pubmed: 31681621.

30. Rawson TM, Moore LSP, Zhu N, et al. Bacterial and fungal co-infection in individuals with coronavirus: A rapid review to support COVID-19 antimicrobial prescribing. Clin Infect Dis. 2020 [Epub ahead of print], doi: 10.1093/cid/ciaa530, indexed in Pubmed: 32358954.

31. Trzonkowski P, Debska-Slizień A, Jankowska M, et al. Immunosenescence increases the rate of acceptance of kidney allotransplants in elderly recipients through exhaustion of CD4+ T-cells. Mech Ageing Dev. 2010; 131(2): 96-104, doi: 10.1016/j. mad.2009.12.006, indexed in Pubmed: 20060852.

32. Trzonkowski P. Effect of anti-influenza vaccination on immune system in the elderly. Handbook on Immunosenescence. Basic Understanding and Clinical Applications. 2009: 1455-1486, doi: 10.1007/978-1-4020-9063-9_70.

33. Strindhall J, Nilsson BO, Löfgren S, et al. No immune risk profile among individuals who reach 100 years of age: findings from the swedish NONA immune longitudinal study. Exp Gerontol. 2007; 42(8): 753-761, doi: 10.1016/j.exger.2007.05.001, indexed in Pubmed: 17606347.

34. Weyand CM, Goronzy JJ. Aging of the Immune System. Mechanisms and Therapeutic Targets. Ann Am Thorac Soc. 2016; 13 (Suppl 5): S422-S428, doi: 10.1513/AnnalsATS.201602-095AW, indexed in Pubmed: 28005419.

35. Bellon M, Nicot C. Telomere dynamics in immune senescence and exhaustion triggered by chronic viral infection. Viruses. 2017; 9(10), doi: 10.3390/v9100289, indexed in Pubmed: 28981470.

36. Trzonkowski P, Myśliwska J, Szmit E, et al. Association between cytomegalovirus infection, enhanced proinflammatory response and low level of anti-hemagglutinins during the anti-influenza vaccination--an impact of immunosenescence. Vaccine. 2003; 21(25-26): 3826-3836, doi: 10.1016/s0264-410x(03)00309-8, indexed in Pubmed: 12922116.

37. Zieliński M, Tarasewicz A, Zielińska H, et al. CD28 positive, cytomegalovirus specific cytotoxic $\mathrm{T}$ lymphocytes as a novel biomarker associated with cytomegalovirus viremia in kidney allorecipients. Journal of Clinical Virology, 2016. J Clin Virol. 2016; 83: 17-25, doi: 10.1016/j.jcv.2016.08.290, indexed in Pubmed: 27526103.

38. Lippi G, Mattiuzzi C, Sanchis-Gomar F, et al. Clinical and demographic characteristics of patients dying from COVID-19 in Italy versus China. J Med Virol. 2020 [Epub ahead of print], doi: 10.1002/jmv.25860, indexed in Pubmed: 32275075.

39. Trzonkowski P, Szmit E, Myśliwska J, et al. CD4+CD25+ T regulatory cells inhibit cytotoxic activity of CTL and NK cells 
in humans-impact of immunosenescence. Clin Immunol. 2006; 119(3): 307-316, doi: 10.1016/j.clim.2006.02.002, indexed in Pubmed: 16545982 .

40. Wang F, Nie J, Wang H, et al. Characteristics of peripheral lymphocyte subset alteration in COVID-19 pneumonia. J Infect Dis. 2020 [Epub ahead of print], doi: 10.1093/infdis/jiaa150, indexed in Pubmed: 32227123.

41. Guan WJ, et al. Clinical Characteristics of Covid-19 in China. N Engl J Med. 2020, doi: 10.1056/nejmc2005203.

42. Wujtewicz M, Dylczyk-Sommer A, Aszkiełowicz A, et al. COVID-19 - what should anaethesiologists and intensivists know about it? Anaesthesiol Intensive Ther. 2020; 52(1): 34-41, doi: 10.5114/ait.2020.93756, indexed in Pubmed: 32191830.

43. Shi CS, Nabar NR, Huang NN, et al. SARS-coronavirus open reading frame- $8 \mathrm{~b}$ triggers intracellular stress pathways and activates NLRP3 inflammasomes. Cell Death Discov. 2019; 5: 101, doi: 10.1038/s41420-019-0181-7, indexed in Pubmed: 31231549.

44. Chen IY, Moivama M, Chang MF. Severe acute respiratory syndrome coronavirus viroporin 3a activates the NLRP3 inflammasome. Front Microbiol. 2019; 50, doi: 10.3389/fmicb.2019.00050, indexed in Pubmed: 30761102.

45. Jaume M, Yip MS, Cheung CY, et al. Anti-severe acute respiratory syndrome coronavirus spike antibodies trigger infection of human immune cells via a $\mathrm{pH}$ - and cysteine protease-independent Fc R pathway. J Virol. 2011; 85(20): 10582-10597, doi: 10.1128/ JVI.00671-11, indexed in Pubmed: 21775467.

46. Hohdatsu T, Yamada M, Tominaga R, et al. Antibody-dependent enhancement of feline infectious peritonitis virus infection in feline alveolar macrophages and human monocyte cell line U937 by serum of cats experimentally or naturally infected with feline coronavirus. J Vet Med Sci. 1998; 60(1): 49-55, doi: 10.1292/ jvms.60.49, indexed in Pubmed: 9492360.

47. Siddiqi HK, Mehra MR. COVID-19 illness in native and immunosuppressed states: A clinical-therapeutic staging proposal. J Heart Lung Transplant. 2020; 39(5): 405-407, doi: 10.1016/j. healun.2020.03.012, indexed in Pubmed: 32362390.

48. Zhao J, Yuan Q, Wang H, et al. Antibody responses to SARS-CoV-2 in patients of novel coronavirus disease. Clin Infect Dis. 2019, doi: 10.1093/cid/ciaa344, indexed in Pubmed: 32221519.

49. Trzonkowski P, Myśliwska J, Pawelec G, et al. From bench to bedside and back: the SENIEUR Protocol and the efficacy of influenza vaccination in the elderly. Biogerontology. 2009; 10(1): 83-94, doi: 10.1007/s10522-008-9155-5, indexed in Pubmed: 18563620.

50. Wills M, Akbar A, Beswick M, et al. Report from the second cytomegalovirus and immunosenescence workshop. Imm Ageing. 2011; 8(1), doi: 10.1186/1742-4933-8-10.

51. Fantuzzi G. Adipose tissue, adipokines, and inflammation. J Allergy Clin Immunol. 2005; 115(5): 911-9; quiz 920, doi: 10.1016/j. jaci.2005.02.023, indexed in Pubmed: 15867843.

52. Isobe KI, Nishio N, Hasegawa T. Immunological aspects of agerelated diseases. World J Biol Chem. 2017; 8(2): 129-137, doi: 10.4331/wjbc.v8.i2.129, indexed in Pubmed: 28588756.

53. Williams H, Cassorla G, Pertsoulis N, et al. Human classical monocytes display unbalanced M1/M2 phenotype with increased atherosclerotic risk and presence of disease. Int Angiol. 2017; 36(2): 145-155, doi: 10.23736/S0392-9590.16.03661-0, indexed in Pubmed: 26871397.

54. Roma-Lavisse C, Tagzirt M, Zawadzki C, et al. M1 and M2 macrophage proteolytic and angiogenic profile analysis in atherosclerotic patients reveals a distinctive profile in type 2 diabetes. Diab Vasc Dis Res. 2015; 12(4): 279-289, doi: 10.1177/1479164115582351, indexed in Pubmed: 25966737.
55. Myśliwska J, Wieckiewicz J, Hak L, et al. Interleukin 6 polymorphism corresponds to the number of severely stenosed coronary arteries. Eur Cytokine Netw. 2006; 17(3): 181-188, indexed in Pubmed: 17194638.

56. Dukat-Mazurek A, Bieniaszewska M, Hellmann A, et al. Association of cytokine gene polymorphisms with the complications of allogeneic haematopoietic stem cell transplantation. Hum Immunol. 2017; 78(11-12): 672-683, doi: 10.1016/j.humimm.2017.09.005, indexed in Pubmed: 28987962.

57. Varga Z, Flammer AJ, Steiger P, et al. Endothelial cell infection and endotheliitis in COVID-19. Lancet. 2020; 395(10234): 1417-1418, doi: 10.1016/S0140-6736(20)30937-5, indexed in Pubmed: 32325026.

58. Sherwood ER, Toliver-Kinsky T. Mechanisms of the inflammatory response. Best Pract Res Clin Anaesthesiol. 2004; 18(3): 385-405, doi: 10.1016/j.bpa.2003.12.002, indexed in Pubmed: 15212335 .

59. Ciceri F, Beretta L, Scandrioglo AM, et al. Microvascular COVID-19 lung vessels obstructive thromboinflammatory syndrome (Micro-CLOTS): an atypical acute respiratory distress syndrome working hypothesis. Crit Care Resusc. 2020, indexed in Pubmed: 32294809.

60. Klok FA, Kruip MJ, van der Meer NJM, et al. Incidence of thrombotic complications in critically ill ICU patients with COVID-19. Thromb Res. 2020 [Epub ahead of print], doi: 10.1016/j. thromres.2020.04.013, indexed in Pubmed: 32291094.

61. Huang Z, Jiang Y, Chen J, et al. Inhibitors of the renin-angiotensin system: The potential role in the pathogenesis of COVID-19. Cardiol J. 2020; 27(2): 171-174, doi: 10.5603/CJ.a2020.0056, indexed in Pubmed: 32286678.

62. Tang N, Li D, Wang X, et al. Abnormal coagulation parameters are associated with poor prognosis in patients with novel coronavirus pneumonia. J Thromb Haemost. 2020; 18(4): 844-847, doi: 10.1111/jth.14768, indexed in Pubmed: 32073213.

63. Danzi GB, Loffi M, Galeazzi G, et al. Acute pulmonary embolism and COVID-19 pneumonia: a random association? Eur Heart J. 2020 [Epub ahead of print], doi: 10.1093/eurheartj/ehaa254, indexed in Pubmed: 32227120.

64. Giannis D, Ziogas IA, Gianni P. Coagulation disorders in coronavirus infected patients: COVID-19, SARS-CoV-1, MERS-CoV and lessons from the past. J Clin Virol. 2020 [Epub ahead of print]; 127: 104362, doi: 10.1016/j.jcv.2020.104362, indexed in Pubmed: 32305883.

65. Thachil J, Tang N, Gando S, et al. ISTH interim guidance on recognition and management of coagulopathy in COVID-19. J Thromb Haemost. 2020; 18(5): 1023-1026, doi: 10.1111/ jth.14810, indexed in Pubmed: 32338827.

66. Idell S. Coagulation, fibrinolysis, and fibrin deposition in acute lung injury. Crit Care Med. 2003; 31(4 Suppl): S213-S220, doi: 10.1097/01.CCM.0000057846.21303.AB, indexed in Pubmed: 12682443.

67. Tersalvi G, Vicenzi M, Calabretta D, et al. Elevated troponin in patients with coronavirus disease 2019: possible mechanisms. J Card Fail. 2020 [Epub ahead of print], doi: 10.1016/j.cardfail.2020.04.009, indexed in Pubmed: 32315733.

68. Kowalik MM, Smiatacz T, Hlebowicz M, et al. Coagulation, coma, and outcome in bacterial meningitis--an observational study of 38 adult cases. J Infect. 2007; 55(2): 141-148, doi: 10.1016/j. jinf.2007.02.002, indexed in Pubmed: 17399791.

69. Kowalik MM, Smiatacz T, Hlebowicz M. Role of coagulation in predicting the outcome of bacterial meningitis. Ann Neurol. 2008; 64(4): 473-4; author reply 474, doi: 10.1002/ana.21318, indexed in Pubmed: 18161880. 
70. Page MJ, Pretorius E. A champion of host defense: a generic large-scale cause for platelet dysfunction and depletion in infection. Semin Thromb Hemost. 2020; 46(3): 302-319, doi: 10.1055/ s-0040-1708827, indexed in Pubmed: 32279287.

71. Zhou F, Yu T, Du R, et al. Clinical course and risk factors for mortality of adult inpatients with COVID-19 in Wuhan, China: a retrospective cohort study. Lancet. 2020; 395(10229): 1054-1062, doi: 10.1016/s0140-6736(20)30566-3.

72. Streiff MB, Agnelli G, Connors JM, et al. Guidance for the treatment of deep vein thrombosis and pulmonary embolism. J Thromb Thrombolysis. 2016; 41(1): 32-67, doi: 10.1007/ s11239-015-1317-0, indexed in Pubmed: 26780738.

73. van Hylckama Vlieg A, Flinterman LE, Bare LA, et al. Genetic variations associated with recurrent venous thrombosis. Circ Cardiovasc Genet. 2014; 7(6): 806-813, doi: 10.1161/CIRCGENETICS.114.000682, indexed in Pubmed: 25210051.

74. Huang J, Huffman JE, Yamakuchi M, et al. Genome-wide association study for circulating tissue plasminogen activator levels and functional follow-up implicates endothelial STXBP5 and STX2. Arterioscler Thromb Vasc Biol. 2014; 34(5): 1093-1101, doi: 10.1161/ATVBAHA.113.302088, indexed in Pubmed: 24578379.

75. Germain M, Chasman D, de Haan H, et al. Meta-analysis of 65,734 Individuals Identifies TSPAN15 and SLC44A2 as Two Susceptibility Loci for Venous Thromboembolism. Am J Hum Genet. 2015; 96(4): 532-542, doi: 10.1016/j.ajhg.2015.01.019.

76. Haan Hde, Bezemer I, Doggen C, et al. Multiple SNP testing improves risk prediction of first venous thrombosis. Blood. 2012; 120(3): 656-663, doi: 10.1182/blood-2011-12-397752.

77. Bruzelius M, Bottai M, Sabater-Lleal M, et al. Predicting venous thrombosis in women using a combination of genetic markers and clinical risk factors. J Thromb Haemost. 2015; 13(2): 219-227, doi: 10.1111/jth.12808, indexed in Pubmed: 25472531.

78. Patnaik MM, Moll S. Inherited antithrombin deficiency: a review. Haemophilia. 2008; 14(6): 1229-1239, doi: 10.1111/j.13652516.2008.01830.x, indexed in Pubmed: 19141163.

79. Wypasek E, Undas A. Protein C and protein S deficiency — practical diagnostic issues. Adv Clin Exp Med. 2013; 22(4): 459-467, indexed in Pubmed: 23986205.

80. Marongiu F, Grandone E, Barcellona D. Pulmonary thrombosis in 2019-nCoV pneumonia? J Thromb Haemost. 2020 [Epub ahead of print], doi: 10.1111/jth.14818, indexed in Pubmed: 32293083.

81. Beun R, Kusadasi N, Sikma M, et al. Thromboembolic events and apparent heparin resistance in patients infected with SARS-CoV-2. Int J Lab Hematol. 2020 [Epub ahead of print], doi: 10.1111/ijlh.13230, indexed in Pubmed: 32311843.

82. Joob B, Wiwanitkit V. Hemorrhagic problem among the patients with COVID-19: clinical summary of 41 thai infected patients. Clin Appl Thromb Hemost. 2020; 26: 1076029620918308, doi: 10.1177/1076029620918308, indexed in Pubmed: 32250159.

83. Tang N, Bai H, Chen X, et al. Anticoagulant treatment is associated with decreased mortality in severe coronavirus disease 2019 patients with coagulopathy. J Thromb Haemost. 2020; 18(5): 1094-1099, doi: 10.1111/jth.14817.

84. Coto-Hernández R, Fábregas Ruano MT. Reply to. J Thromb Haemost. 2020 [Epub ahead of print], doi: 10.1111/jth.14852, indexed in Pubmed: 32302445.

85. Moore $\mathrm{HB}$, Barrett $\mathrm{CD}$, Moore EE, et al. Is there a role for tissue plasminogen activator (tPA) as a novel treatment for refractory COVID-19 associated acute respiratory distress syndrome (ARDS)? J Trauma Acute Care Surg. 2020 [Epub ahead of print], doi: 10.1097/TA.0000000000002694, indexed in Pubmed: 32281766.
86. Zhang Y, Xiao M, Zhang S, et al. Coagulopathy and Antiphospholipid Antibodies in Patients with Covid-19. N Engl J Med. 2020; 382(17): e38, doi: 10.1056/NEJMc2007575, indexed in Pubmed: 32268022.

87. Kowalik MM. Influence of intravascular coagulation on brain injury and clinical course in purulent meningitis. Przeglad Epidemiologiczny. 2006; 60(2): 273-280.

88. Helms J, Kremer S, Merdji H, et al. Neurologic features in severe SARS-CoV-2 infection. N Engl J Med. 2020 [Epub ahead of print], doi: 10.1056/NEJMc2008597, indexed in Pubmed: 32294339.

89. Wu Z, McGoogan JM. Characteristics of and important lessons from the coronavirus disease 2019 (COVID-19) outbreak in china: summary of a report of 72314 cases from the chinese center for disease control and prevention. JAMA. 2020 [Epub ahead of print], doi: 10.1001/jama.2020.2648, indexed in Pubmed: 32091533.

90. Onder G, Rezza G, Brusaferro S. Case-Fatality rate and characteristics of patients dying in relation to COVID-19 in italy. JAMA. 2020 [Epub ahead of print], doi: 10.1001/jama.2020.4683, indexed in Pubmed: 32203977.

91. $\mathrm{Hu} \mathrm{H}$, Yao Ni, Qiu Y. Comparing rapid scoring systems in mortality prediction of critical ill patients with novel coronavirus disease. Acad Emerg Med. 2020 [Epub ahead of print], doi: 10.1111/ acem.13992, indexed in Pubmed: 32311790.

92. Dzieciatkowski T, Szarpak L, Filipiak KJ, et al. COVID-19 challenge for modern medicine. Cardiol J. 2020; 27(2): 175-183, doi: 10.5603/CJ.a2020.0055, indexed in Pubmed: 32286679.

93. Kellum JA. KDIGO Clinical Practice Guideline for Acute Kidney Injury. Kidney International Supplements. 2012; 2(2): 1-141.

94. Fanelli V, Fiorentino M, Cantaluppi V, et al. Acute kidney injury in SARS-CoV-2 infected patients. Crit Care. 2020; 24(1): 155, doi: 10.1186/s13054-020-02872-z, indexed in Pubmed: 32299479.

95. Su H, Yang M, Wan C, et al. Renal histopathological analysis of 26 postmortem findings of patients with COVID-19 in China. Kidney Int. 2020 [Epub ahead of print], doi: 10.1016/j. kint.2020.04.003, indexed in Pubmed: 32327202.

96. Zheng YY, Ma YT, Zhang JY, et al. COVID-19 and the cardiovascular system. Nat Rev Cardiol. 2020; 17(5): 259-260, doi: 10.1038/s41569-020-0360-5.

97. Xiong TY, Redwood S, Prendergast B, et al. Coronaviruses and the cardiovascular system: acute and long-term implications. Eur Heart J. 2020 [Epub ahead of print], doi: 10.1093/eurheartj/ ehaa231, indexed in Pubmed: 32186331.

98. Guo T, Fan Y, Chen M, et al. Cardiovascular implications of fatal outcomes of patients with coronavirus disease 2019 (COVID-19). JAMA Cardiol. 2020 [Epub ahead of print], doi: 10.1001/jamacardio.2020.1017, indexed in Pubmed: 32219356.

99. Huang C, Wang Y, Li X, et al. Clinical features of patients infected with 2019 novel coronavirus in Wuhan, China. Lancet. 2020; 395(10223): 497-506, doi: 10.1016/s0140-6736(20)30183-5.

100. Shi S, Qin Mu, Shen Bo, et al. Association of cardiac injury with mortality in hospitalized patients with COVID-19 in Wuhan, China. JAMA Cardiol. 2020 [Epub ahead of print], doi: 10.1001/ jamacardio.2020.0950, indexed in Pubmed: 32211816.

101. Hamming I, Timens W, Bulthuis MLC, et al. Tissue distribution of ACE2 protein, the functional receptor for SARS coronavirus. A first step in understanding SARS pathogenesis. J Pathol. 2004; 203(2): 631-637, doi: 10.1002/path.1570, indexed in Pubmed: 15141377.

102. Zou X, Chen Ke, Zou J, et al. Single-cell RNA-seq data analysis on the receptor ACE2 expression reveals the potential risk of different human organs vulnerable to $2019-\mathrm{nCoV}$ infection. Front Med. 2020 [Epub ahead of print], doi: 10.1007/s11684-020-07540, indexed in Pubmed: 32170560. 
103. Chen L, Li X, Chen M, et al. The ACE2 expression in human heart indicates new potential mechanism of heart injury among patients infected with SARS-CoV-2. Cardiovasc Res. 2020; 116(6): 1097-1100, doi: 10.1093/cvr/cvaa078, indexed in Pubmed: 32227090.

104. Mehra MR, Desai SS, Kuy S, et al. Cardiovascular disease, drug therapy, and mortality in covid-19. N Engl J Med. 2020 [Epub ahead of print], doi: 10.1056/NEJMoa2007621, indexed in Pubmed: 32356626.

105. Brojakowska A, Narula J, Shimony R, et al. Clinical implications of SARS-Cov2 interaction with renin angiotensin system. J Am Coll Cardiol. 2020 [Epub ahead of print], doi: 10.1016/j. jacc.2020.04.028, indexed in Pubmed: 32305401.

106. Kuster GM, Pfister O, Burkard T, et al. SARS-CoV2: should inhibitors of the renin-angiotensin system be withdrawn in patients with COVID-19? Eur Heart J. 2020 [Epub ahead of print], doi: 10.1093/eurheartj/ehaa235, indexed in Pubmed: 32196087.

107. Vaduganathan M, Vardeny O, Michel T, et al. Renin-angiotensin-aldosterone system inhibitors in patients with COVID-19. N Engl J Med. 2020; 382(17): 1653-1659, doi: 10.1056/NEJMsr2005760, indexed in Pubmed: 32227760.

108. Danser AH, Epstein M, Batlle D. Renin-angiotensin system blockers and the COVID-19 pandemic: at present there is no evidence to abandon renin-angiotensin system blockers. hypertension. 2020 [Epub ahead of print]: HYPERTENSIONAHA12015082, doi: 10.1161/ HYPERTENSIONAHA.120.15082, indexed in Pubmed: 32208987.

109. Maffia P, Guzik TJ. When, where, and how to target vascular inflammation in the post-CANTOS era? Eur Heart J. 2019; 40(30): 2492 -2494, doi: 10.1093/eurheartj/ehz133, indexed in Pubmed: 30929007.

110. Clerkin KJ, Fried JA, Raikhelkar J, et al. Coronavirus disease 2019 (COVID-19) and cardiovascular disease. Circulation. 2020; 2020, doi: 10.1161/CIRCULATIONAHA.120.046941, indexed in Pubmed: 32200663.

111. Patel AB, Verma A. COVID-19 and angiotensin-converting enzyme inhibitors and angiotensin receptor blockers: what is the evidence? JAMA. 2020 [Epub ahead of print], doi: 10.1001/ jama.2020.4812, indexed in Pubmed: 32208485.

112. Xu Z, Shi L, Wang Y, et al. Pathological findings of COVID-19 associated with acute respiratory distress syndrome. Lancet Respir Med. 2020; 8(4): 420-422, doi: 10.1016/s2213-2600(20)30076-x.

113. Wang $\mathrm{D}, \mathrm{Hu} \mathrm{Bo}, \mathrm{Hu} \mathrm{C}$, et al. Clinical characteristics of 138 hospitalized patients with 2019 novel coronavirus-infected pneumonia in Wuhan, China. JAMA. 2020 [Epub ahead of print], doi: 10.1001/ jama.2020.1585, indexed in Pubmed: 32031570.

114. Maekawa Y, Ouzounian M, Opavsky MA, et al. Connecting the missing link between dilated cardiomyopathy and viral myocarditis: virus, cytoskeleton, and innate immunity. Circulation. 2007; 115(1): 5-8, doi: 10.1161/CIRCULATIONAHA.106.670554, indexed in Pubmed: 17200452.

115. Ferrario CM, Jessup J, Chappell MC, et al. Effect of angiotensin-converting enzyme inhibition and angiotensin II receptor blockers on cardiac angiotensin-converting enzyme 2. Circulation. 2005; 111(20): 2605-2610, doi: 10.1161/CIRCULATIONAHA.104.510461, indexed in Pubmed: 15897343.

116. Varga Z, Flammer AJ, Steiger P, et al. Endothelial cell infection and endotheliitis in COVID-19. Lancet. 2020; 395(10234): 1417-1418, doi: 10.1016/S0140-6736(20)30937-5, indexed in Pubmed: 32325026.

117. Bonetti P, Lerman L, Lerman A. Endothelial dysfunction. Arterioscler Thromb Vasc Biol. 2003; 23(2): 168-175, doi: 10.1161/01. atv.0000051384.43104.fc.

118. Yin S, Huang M, Li D, et al. Difference of coagulation features between severe pneumonia induced by SARS-CoV2 and nonSARS-CoV2. J Thromb Thrombolysis. 2020 [Epub ahead of print], doi: 10.1007/s11239-020-02105-8, indexed in Pubmed: 32246317.

119. Driggin E, Madhavan MV, Bikdeli B, et al. Cardiovascular considerations for patients, health care workers, and health systems during the coronavirus disease 2019 (COVID-19) pandemic. J Am Coll Cardiol. 2020 [Epub ahead of print], doi: 10.1016/j. jacc.2020.03.031, indexed in Pubmed: 32201335.

120. Drummond GR, Vinh A, Guzik TJ, et al. Immune mechanisms of hypertension. Nat Rev Immunol. 2019; 19(8): 517-532, doi: 10.1038/s41577-019-0160-5, indexed in Pubmed: 30992524.

121. Sanders JM, Monogue ML, Jodlowski TZ, et al. Pharmacologic treatments for coronavirus disease 2019 (COVID-19): a review. JAMA. 2020 [Epub ahead of print], doi: 10.1001/jama.2020.6019, indexed in Pubmed: 32282022.

122. Molina JM, Delaugerre C, Le Goff J, et al. No evidence of rapid antiviral clearance or clinical benefit with the combination of hydroxychloroquine and azithromycin in patients with severe COVID-19 infection. Med Mal Infect. 2020 [Epub ahead of print], doi: 10.1016/j.medmal.2020.03.006, indexed in Pubmed: 32240719 .

123. Cao B, Wang Y, Wen D, et al. A trial of lopinavir-ritonavir in adults hospitalized with severe COVID-19. N Engl J Med. 2020 [Epub ahead of print], doi: 10.1056/NEJMoa2001282, indexed in Pubmed: 32187464.

124. Cortegiani A, Ingoglia G, Ippolito M, et al. A systematic review on the efficacy and safety of chloroquine for the treatment of $\mathrm{CO}$ VID-19. J Crit Care. 2020 [Epub ahead of print], doi: 10.1016/j. jcrc.2020.03.005, indexed in Pubmed: 32173110.

125. Gilead, Gilead's Investigational Antiviral Remdesivir Receives U.S. Food and Drug Administration Emergency Use Authorization for the Treatment of COVID-19. 2020, Gilead.

126. Wu C, Liu Y, Yang Y, et al. Analysis of therapeutic targets for SARS-CoV-2 and discovery of potential drugs by computational methods. Acta Pharm Sin B. 2020, doi: 10.1016/j. apsb.2020.02.008.

127. Chu CM, Poon LLM, Cheng VCC, et al. Initial viral load and the outcomes of SARS. CMAJ. 2004; 171(11): 1349-1352, doi: 10.1503/cmaj.1040398, indexed in Pubmed: 15557587.

128. Jacobs JP, Stammers AH, St Louis J, et al. Extracorporeal membrane oxygenation in the treatment of severe pulmonary and cardiac compromise in COVID-19: experience with 32 patients. ASAIO J. 2020 [Epub ahead of print], doi: 10.1097/ MAT.0000000000001185, indexed in Pubmed: 32317557.

129. Nicola M, O’Neill N, Sohrabi C, et al. Evidence based management guideline for the COVID-19 pandemic - review article. Int J Surg. 2020, doi: 10.1016/j.ijsu.2020.04.001, indexed in Pubmed: 32289472

130. Duan K, Liu B, Li C, et al. Effectiveness of convalescent plasma therapy in severe COVID-19 patients. Proc Natl Acad Sci USA. 2020; 117(17): 9490-9496, doi: 10.1073/pnas.2004168117, indexed in Pubmed: 32253318.

131. Shen C, Wang $Z$, Zhao F, et al. Treatment of 5 critically ill patients with COVID-19 with convalescent plasma. JAMA. 2020 [Epub ahead of print], doi: 10.1001/jama.2020.4783, indexed in Pubmed: 32219428.

132. Dalli J, Winkler JW, Colas RA, et al. Resolvin D3 and aspirintriggered resolvin D3 are potent immunoresolvents. Chem Biol. 2013; 20(2): 188-201, doi: 10.1016/j.chembiol.2012.11.010, indexed in Pubmed: 23438748.

133. Colby JK, Abdulnour REE, Sham HoP, et al. Resolvin D3 and aspirin-triggered resolvin D3 are protective for injured epithelia. Am J Pathol. 2016; 186(7): 1801-1813, doi: 10.1016/j. ajpath.2016.03.011, indexed in Pubmed: 27171898.

134. Arnardottir H, Dalli J, Colas R, et al. Aging delays resolution of acute inflammation in mice: reprogramming the host response with novel nano-proresolving medicines. J Immunol. 2014; 193(8): 4235-4244, doi: 10.4049/jimmunol.1401313.

135. Duvall MG, Levy BD. DHA- and EPA-derived resolvins, protectins, and maresins in airway inflammation. Eur J Pharmacol. 2016; 785: 144-155, doi: 10.1016/j.ejphar.2015.11.001, indexed in Pubmed: 26546247. 